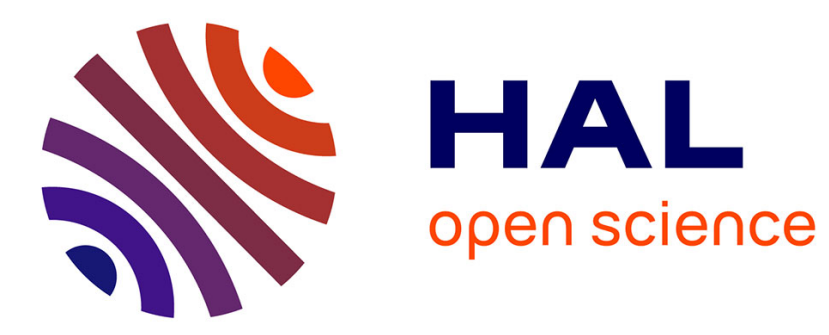

\title{
Stability periods between financial crises: The role of macroeconomic fundamentals and crises management policies
}

\author{
Zorobabel Bicaba, Daniel Kapp, Francesco Molteni
}

\section{To cite this version:}

Zorobabel Bicaba, Daniel Kapp, Francesco Molteni. Stability periods between financial crises: The role of macroeconomic fundamentals and crises management policies. 2011. halshs-00639869

\section{HAL Id: halshs-00639869 \\ https://shs.hal.science/halshs-00639869}

Submitted on 10 Nov 2011

HAL is a multi-disciplinary open access archive for the deposit and dissemination of scientific research documents, whether they are published or not. The documents may come from teaching and research institutions in France or abroad, or from public or private research centers.
L'archive ouverte pluridisciplinaire HAL, est destinée au dépôt et à la diffusion de documents scientifiques de niveau recherche, publiés ou non, émanant des établissements d'enseignement et de recherche français ou étrangers, des laboratoires publics ou privés. 


\section{Documents de Travail du Centre d'Economie de la Sorbonne}

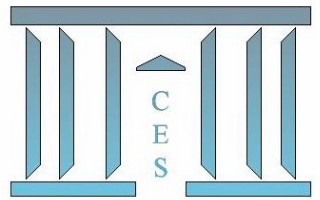

Stability periods between financial crises :

The role of macroeconomic fundamentals and crises management policies

Zorobabel BICABA, Daniel KAPP, Francesco MOLTENI

2011.64

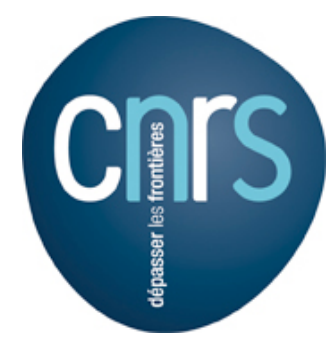




\title{
Stability periods between financial crises:
}

\section{The role of macroeconomic fundamentals}

\author{
and crises management policies*
}

\author{
Zorobabel Bicaba ${ }^{\dagger}$, Daniel Kapp $^{\ddagger}$, Francesco Molteni $^{\S}$
}

October 14, 2011

\begin{abstract}
The aim of this paper is to identify which factors explain why some countries are more prone to enjoy long durations of stability, while others experience crises in shorter intervals.

To this end, we analyze the duration of stability periods between currency, debt, and banking crises from 1980 to 2008. We find that durations of tranquility between currency and debt crises are bimodally distributed, making conventional econometric models unsuitable. Therefore, we introduce an innovative econometric strategy, the Finite Mixture Model.

Real and financial variables are found to have high predictive power for the spell of stability between currency crises, while for debt crises, the real interest rate is observed to be the best predictor. The time between the occurrence of systemic financial crises is prolonged through large-scale government interventions and IMF aid programs, while recapitalization turns out to have a negative impact.
\end{abstract}

Code JEL. C14 C16 C41 G01 G18 H12

keywords:Financial crises, Finite mixture model, duration, bimodality.

*We thank Professor Fabrizio Coricelli for his helpful comments and the participants of the Doctoral Seminar at the Pantheon-Sorbonne University of Paris1, of the Orleans Doctoral Development Days, of the Macro Ph.D. seminar at the PSE, of the Central Bank of Peru Research Seminar and of the Bi-annual meeting of the UP1 Doctoral School EPS.

${ }^{\dagger}$ University of Paris 1 - Panthéon-Sorbonne, Paris School of Economics and CERDI. Corresponding email address: Zorobabel.Bicaba@malix.univ-paris1.fr.

${ }^{\ddagger}$ University of Paris 1 - Panthéon-Sorbonne, Paris School of Economics. Corresponding email address: Daniel.Kapp@malix.univ-paris1.fr.

$\S$ University of Paris 1 - Panthéon-Sorbonne, Paris School of Economics. Corresponding email address: Francesco.Molteni@malix.univ-paris1.fr. 


\section{Introduction}

Recent public and academic debates have predominantly revolved around the onset and direct recovery from financial crises episodes. Some scholars, such as Reinhart and Rogoff (2010/09)have however turned their attention to the recurrence of banking crises. They show that these perennial events have occurred at a relatively stable frequency in both emerging and established market nations. An even smaller share of the literature has been devoted to the fact that some countries have faced more crises than others. To the best of our knowledge, none of the studies carried out so far has examined the determinants of the length of stability periods between financial crises.

The frequency of financial crises has, amongst others, been analyzed by Jordà, Schularick and Taylor (2010) who investigate empirically if crises can be predicted by macroeconomic fundamentals or whether they are randomly distributed events. The authors conclude that most financial crises occur randomly. Regarding the behavior of macroeconomic variables during pre- and postcrises periods, they find that such events are preceded by low natural interest rates and rising credit, while a large share of financial crises episodes are followed by recessions. Distinguishing between "normal" recessions during the business cycle and recessions accompanied by financial crises, they discover that the latter ones are one third more costly in terms of output losses.

Tudela (2004) adopts a duration model approach to analyze the determinants of currency crises. One of the main objectives of the study is to test for time dependence, that is, the length of the time already spent in a tranquil period as a determinant of the probability of exit into a crisis state. A justification for the use of this framework is that duration models allow to account for duration dependence amongst the determinants of the likelihood of speculative attacks, without neglecting the use of time-varying explanatory variables. The results exhibit the existence of a highly significant negative duration dependence. The highest probability to exit into a currency crises state is therefore observed during the initial phase of the tranquil period.

While the duration between crises is directly linked to the frequency of crises, distinct conclusions can be drawn from the analysis of either one. Dissimilar economic fundamentals could be at play in a country experiencing a certain number of crises clustered over a short period of time, and another country experiencing the same number of crises spread out over a larger period of time. By examining entire periods of stability we can take into account and disentangle 
factor development during the period of recovery and consider the immediate time span before financial turmoil occurs.

This study therefore estimates various models analyzing the duration between different types of financial crises in order to identify whether some variables explain why some countries are more prone to enjoy long durations of stability, while others experience crises in shorter intervals.

In order to do so, we analyze the duration of stability periods between currency, debt, and banking crises from 1980 to 2008. The distribution of this variable appears to be bimodal regarding currency and debt crisis. Two groups of observations emerge: one depicting average stability periods of around 5 years and a second group experiencing crises roughly each 15 years. The distribution of the duration between banking crises is unimodal with a peak at 11 years.

From a methodological point of view, the existence of bimodal distributions of durations between currency and debt crises makes traditional econometric methods non-valid. One of the main contributions of this paper is that it uses an innovative approach which is robust to the problems of asymmetric, skewed, or multimodal distributions, namely the Finite Mixture Model (FMM).

The FMM is estimated separately for currency and debt crises including 3 groups of concomitant variables: real variables (Investment, GDP per capita, real interest rate), financial and monetary variables (M2 / reserves, Credit / GDP, Net Foreign asset / GDP), as well as equilibrium or external sector variables (Current Account / GDP, the real exchange rate, and terms of trade). For each variable, we distinguish between the long term (recovery) and immediate pre-crisis impact. The model permits differentiation between the effects of an explanatory variable on the probability of belonging to either group of observations and on the variability within both groups. Finally, we focus on systemic financial crises analyzing the impact of different macroeconomic and regulatory policies on the stability periods after those episodes.

Some of the main findings regarding stability periods between currency crises are that high GDP growth in the three years prior to a currency crises tends to postpone potential crises conditional on the observation belonging to the group of relatively short stability periods of five years. An increase in the real interest rate during the three years prior to a crisis decreases the duration of stability periods. An accumulation of net foreign assets does prove to be an effective mean to prolong stability periods. Regarding the real exchange rate, we capture an effect in line 
with the second generation of self fulfilling crises models.

We find that our results are consistent with the debt sustainability literature and that the main country characteristics usually considered by rating agencies in order to classify sovereign default risk are statistically significant in explaining the length of stability periods between debt crises.

The FMM model is found to predict durations between financial crises fairly well. Clear differences between the predictive power of the different groups of variables exist.

An expansionary fiscal policy during the first three years after a systemic banking crisis has no effect on the duration of the length of the stability period.

The duration of stability periods after systemic crises decreases with the level of the maximum of liquidity support in percentage of deposit that monetary authorities accorded to banks. It is however not influenced by the reduction of reserve requirements in the three years following a crisis. We conclude that only large-scale government interventions in banks have a reducing effect on the length of stability periods after a systemic banking crisis.

Large-scale government interventions may help to restore the confidence in banks and to sustain accelerated recovery of the economy. In addition, an adoption of IMF programs during and/or after a systemic banking crisis may help to stabilize the economy.

The remainder of this paper is organized as follows: Section 2 introduces the data used and preliminary statistics on the occurrence of financial crises and the duration between them. Section 3 presents the methodology, introducing the Finite Mixture Model and explains the choice and computation of the concomitant variables. Section 4 offers bootstrap estimations as a solution to the small sample issue and estimation results concerning stability periods between currency and debt crises. The predictive quality of each group of variables is assessed. Section 5 provides policy recommendations after systemic financial crises. Section 6 concludes. 


\section{Data and descriptive statistics}

\section{$2.1 \quad$ Data}

This study uses annual data from 1960 through 2008 for 176 developing and developed countries. Sources for macroeconomic indicators are shown in the appendix, Table 13.

\section{- Financial Crises Indicators}

Financial crises indicators are taken from Laeven and Valencia (2008). Currency, banking, and debt crises are identified over the period from 1970 to 2008.

The existence of a banking crisis is evaluated on the basis of a number of quantitative and subjective criteria, such as a large number of defaults and a high quantity of non-performing loans. This can be caused by factors such as depressed asset prices, sharp increases in the real interest rate, capital flow reversals, or depositor runs on banks.

The starting year of a currency crisis is identified building on an approach developed in Frankel and Rose (1996). A currency crisis is thus defined as a nominal depreciation of the respective currency of at least 30 percent, which is also at least a 10 percent increase in the rate of depreciation compared to the year before. Their list also comprises large devaluations by countries under fixed exchange rate regimes.

Sovereign debt crises are reported in the case of sovereign defaults to private lending and in a year of debt rescheduling.

We identify the starting year of a systemic crisis (twin or triple crisis) as the occurrence of a banking or currency crisis in year t, combined with at least one other type of crisis during the period $[\mathrm{t}-1, \mathrm{t}+2]$.

As can be seen in Figure 1, the number of currency crises peaked during the early eighties and again during the early nineties with the occurrence of around 30 currency crises per year. After the Asian financial turmoil during the late nineties, currency crises have become less frequent.

Banking crises have in general been less frequent than currency crises and peaked during the early nineties (as amongst others, several Latin American countries experienced difficulties defending their exchange rates, resulting in large problems in their banking sectors). The number of banking crises per year increased during the late eighties up to its high in 1994 with 18 crises 
per year and from then on decreased to a low of two banking crises in the year 2003. Debt crises occurred mainly during the early eighties and stayed at a low level until the year 2002, when Urugay, Dominica, Gabon, and Moldova struggled to repay their debt. Debt crises nearly ceased to exist until recently, as only the Dominican Republic in 2003 and Grenada in 2004 had to reschedule their debt. Recently, several European countries are experiencing difficulties in repaying their debt. Debt crises should therefore not be dismissed as a past phenomena but could well be a recurrent phenomenon in the close future.

Relatively few financial crises have occurred during the late 1970s after the fall of the Bretton Woods system in 1971-1973. A period of high stability was observed until early 1980. The financial crises that followed after 1980 started becoming a more frequently observed phenomena subsequently. These crises are believed to follow different underlying causes than the crises in early 1970, as countries after the fall of the Bretton Woods system largely conducted their own monetary policy and shifted towards more or less flexible exchange rate policies. Capital flow liberalization was taken onto the political agenda after 1973, changing fundamentals for financial crises episodes. Due to these reasons and a significant increase in data availability, the starting point for our analysis is set at 1980, leaving a period of 29 years from 1980 until 2008 covering 163 currency crises, 111 banking crises, and 52 debt crises.

\section{- Duration of stability between financial crises}

We consider a duration of stability between financial crises to be specific for each currency-, debt-, and banking crises in each country. A duration of tranquility starts the year after the onset of a financial crisis observed in the respective country, and continues until observance of the same type of crisis, independent of eventual onsets of one of the other two types of crises. The data is left censored as 1980 is defined as the onset of a period of stability for all countries. Since a period of stability necessarily has to be ended by another crisis of the same type as marks the onset, a duration is not registered as such if no crisis has occurred after the last crisis until 2008. The resulting number of stability periods is consequently the same as the number of financial crises episodes. 
Figure 1: Distribution of financial crises

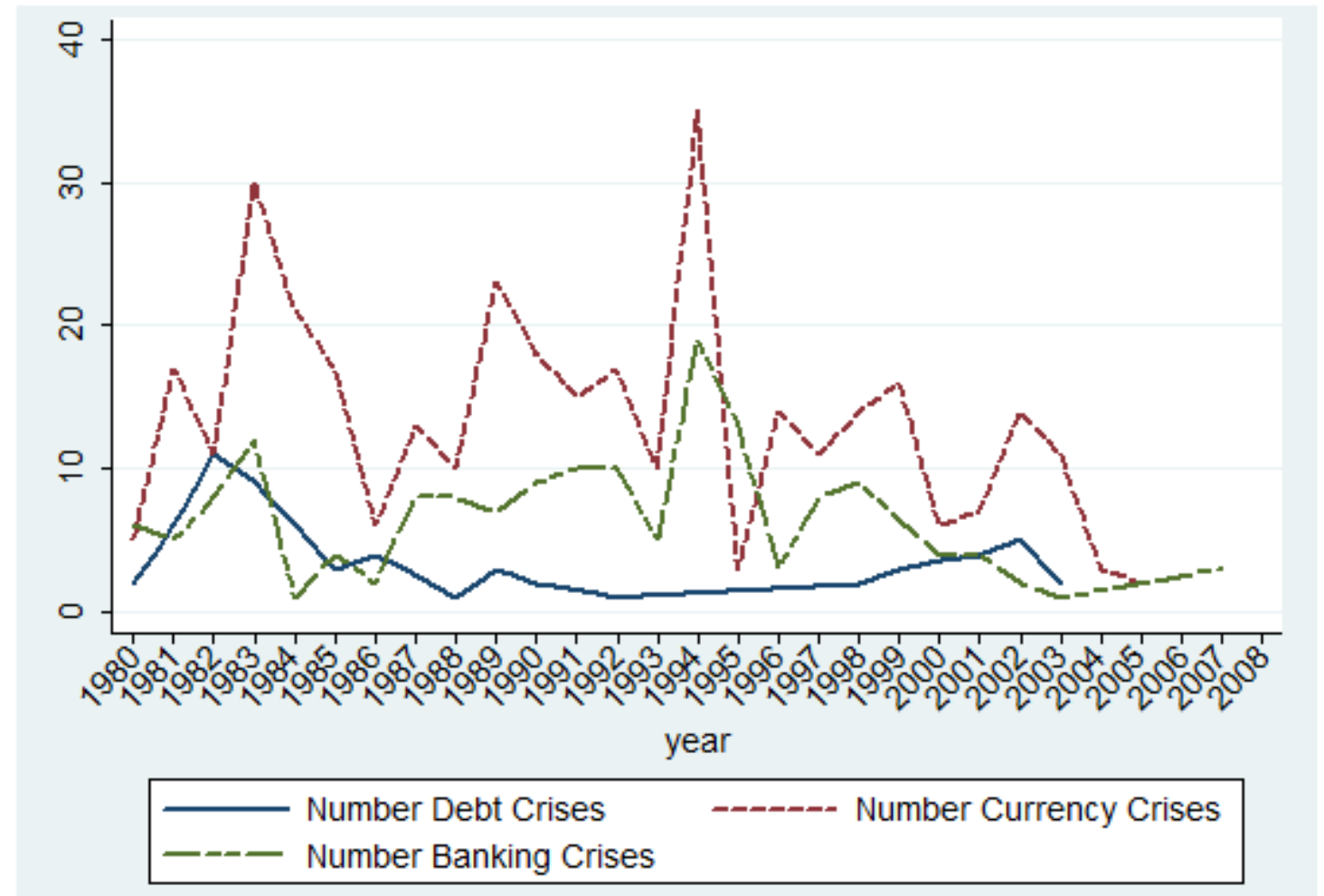

${ }^{1}$ Source: Authors' calculations

\subsection{Descriptive Statistics}

\subsubsection{Kernel density of duration}

The histograms and kernel density functions of stability periods for all three types of crises are displayed in Figure 2. Periods of stability between currency crises last on average nine years, with the minimum duration of stability being two years and the maximum being 23 years. The longest periods of stability between currency crises have been enjoyed by Libya and Guinea, which experienced their first currency crises in 2002 and 2005 respectively. 53 stability periods of less or equal to five years can be observed. A large share of these short stability periods are experienced by Latin American countries.

The average length of stability periods between debt crises is 8.6 years, with the shortest 
period lasting for two years and the longest lasting 29 years, while the average duration of stability between banking crises is longer (11.5 years) than the duration between currency or debt crises. The higher average is however driven by a group of high income countries which have never experienced a banking crisis.

In order to treat our data statistically and to identify driving factors of different durations of stability periods within each group of crises, we first take a closer look at each distribution of length of periods between crises.

Figure 2: Histogram and Kernel density of durations
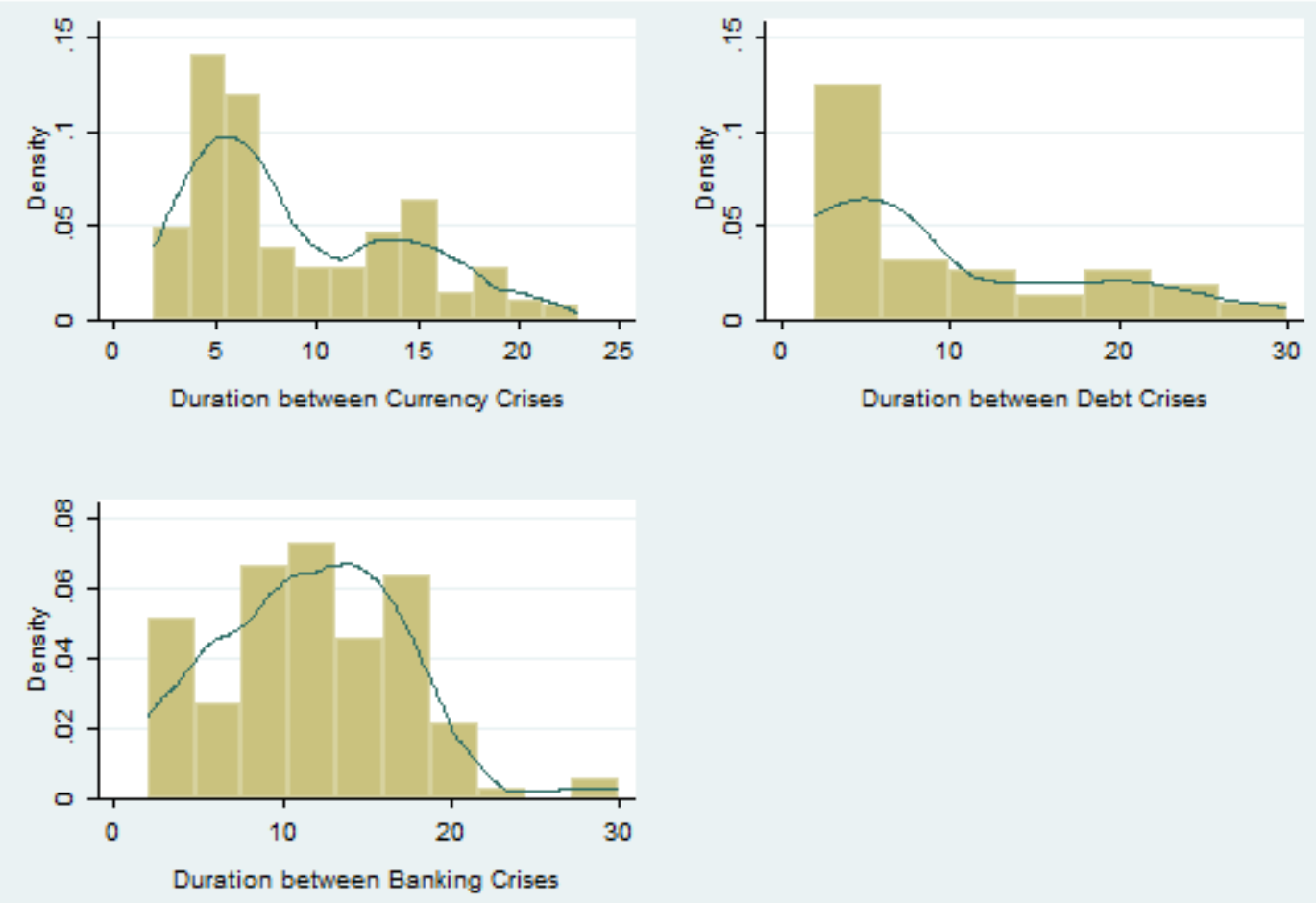

${ }^{2}$ Source: Authors' calculations

Examination of the kernel densities depicted in Figure 2 suggests that stability periods between currency and debt crises are not normally distributed. The density functions of durations between currency and debt crises suggest bimodal distributions, while periods of stability between banking crises are "unimodally distributed" . Two groups of durations between currency crises exist. In the first group, currency crises take place on average every 5 years, while the av- 
erage duration of stability in group two is roughly 15 years. Durations of stability between debt crises portray a bimodal distribution around 4 and 20 years, even though bimodality of stability duration is less pronounced than for currency crises. Periods between banking crises seem to be unimodally distributed. The picture changes once durations are decomposed for different income groups.

Figure 3: Kernel density of durations: World Bank income groups
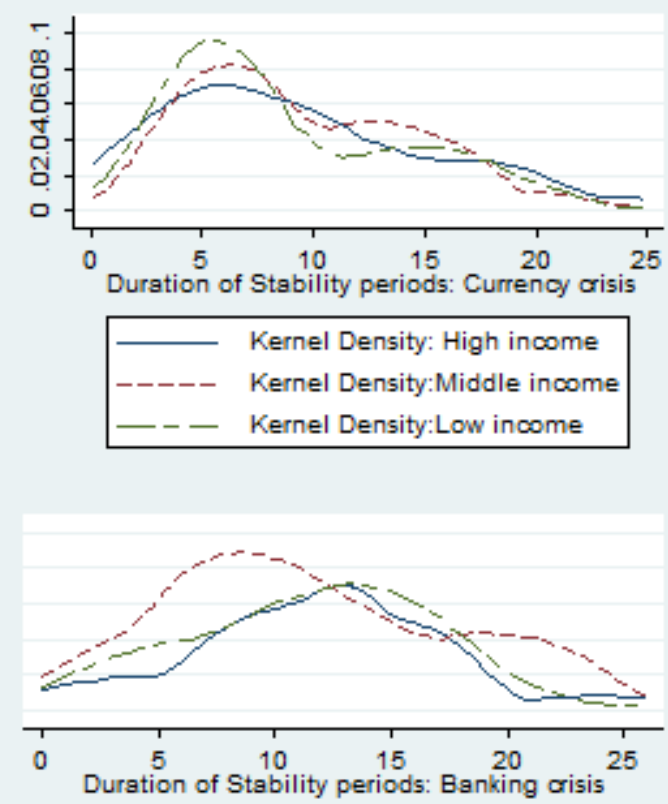

Duration of Stability periods: Banking crisis

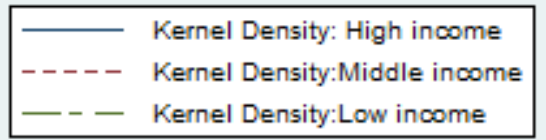

${ }^{3}$ Source: Authors' calculations

Figure 3. shows the underlying distributions for each kernel density function per income group as defined by the World Bank. Stability periods between currency crises are bimodally distributed for every income group. Low income countries on average experience shorter durations of stability, while their bimodality is most pronounced. Middle income countries seem to be the most homogenous group in terms of durations of stability periods, experiencing longer periods of stability in both clusters of durations. High income countries experienced a higher share of stability periods of longer than 18 years then the remaining two income groups. Their 
distribution of stability durations is nearly unimodal and skewed with a tail to the right.

Stability periods for debt crises can only be depicted for low and middle income countries as there are not enough debt crises episodes for high income countries in the sample in order to calculate the kernel density function. Both distributions are bimodally distributed. Middle income countries do not in general experience longer periods between debt crises but do experience fewer debt crises in general.

The distribution of durations for banking crises is most heterogeneous between income groups. While the distributions for high and low income countries are unimodal, middle income countries are split in two groups with a peak corresponding to a very short duration of stability periods. This seems consistent with Gaytan and Ranciere (2006) who show that for middle income countries financial development has a positive long term effect on growth but makes countries more prone to banking crisis. Tornell and Westermann (2002, 2003) observe that after liberalization of financial markets, macro variables of middle income countries followed a marked boom and bust pattern due to credit market imperfections. The authors explain that these economies are characterized by a prominent non-tradable sector. This sector is more banking dependent and depicts a significant degree of maturity mismatch. A real depreciation in the non-tradable sector has balance sheet effects which amplify the initial negative shock. In addition, the credit channel is more important for countries with less access to foreign capital markets.

Due to the bimodality of stability periods as such and their heterogenous underlying distributions, a method is proposed which employs the statistical properties of bimodal distributions and clustering of observations over time. As asymmetric bimodal densities are observed for currency crises and debt crises, normal mixture densities are chosen to model the distribution of data as proposed by Pearson (1894).

\subsubsection{Quantile-Quantile (QQ) Plot : Test for randomness of crises occurrence}

In order to report robust results, it is inevitable to confirm if and how it is valid to pool observations across countries and time into a single sample. If one assumes that the arrival of crises is independent across countries, then it is possible to pool the duration between financial crises in a single sample without experiencing any econometric issues. Otherwise, a manifestation of clustering over time in data would result in an empirical distribution of the data being over- 
dispersed. In this case, a specific estimation strategy consistent with over-dispersed distribution is needed.

To do so, we follow a strategy employed byJordà, Taylor and al.(2010), adopting the Q-Q plot non parametric test for diagnosing random occurrence of financial crises (i.e temporal clustering of crises events ). In this test, financial crises are evaluated by Bernoulli trials with probability p: Under the null hypothesis, durations between crises events are distributed as a geometric random variable. Under the alternative, crises appear in clusters, meaning that we are likely to observe a high proportion of small durations relative to the theoretical quintals implied by the geometric distribution, thus generating over- dispersion.

The main idea of this test is to evaluate, given a random sample of univariate data points, whether this sample comes from a specified distribution F. Rather than considering individual quantiles, the QQ plot considers the sample as a whole and draws the sample quantiles against the theoretical quantiles of the specified target distribution F. As a theoretical distribution, we use a geometric distribution which evaluates the probability of being in state $\mathrm{k}$ in $\mathrm{t}$, given the fact that we are in state $\mathrm{m}$ during the last ( $\mathrm{t}-1)$ periods.

Concretely, this theoretical distribution can be formulated as follows. Let $d_{k}$ be the duration between two financial crises which occurred at $\mathrm{t}$ and $\mathrm{t}+d_{k}$ respectively, and $\mathrm{q}$ the probability that a given country experiences a crisis at $t$. The probability that this country falls and remains into a period of stability until $\mathrm{t}+d_{k}$, given the fact that it has experienced a financial crisis at $\mathrm{t}$, is equal to:

$$
P=\operatorname{Prob}\left(D=d_{k}\right)=q(1-q)^{d_{k}-1}
$$

Where $q=\frac{\sum_{k} I_{k}}{N}$ is the maximum likelihood estimator of financial crisis occurrence probability; with $I_{k}$ representing an indicative variable which is equal to 1 at the date of financial crisis and 0 otherwise. $\mathrm{N}$ is the number of observations in the sample.

The empirical density of our data is estimated using an epanechnikov kernel density:

$$
\hat{f}_{n}=\frac{1}{n} \sum_{i}^{n} K_{n}\left(d-d_{i}\right)=\frac{1}{n h} \sum_{i}^{n} K_{n}\left(\frac{d-d_{i}}{h}\right)
$$

where $\mathrm{K}$ is the kernel; a symmetric but not necessarily positive function that integrates to 
one. Let $F_{n}(d)=\frac{1}{n} \sum_{1}^{n} I\left(d_{i} \leq d\right)$ represent the cumulative distribution function of duration, then the QQ plot statistic is given by the random closed set such as:

$$
S_{n}=\left\{\inf \left\{d: F(d) \geq \frac{i}{n+1}\right\}, D_{i: n}, 1 \leq i \leq n\right\}
$$

The QQ plot test consequently compares the theoretical quantiles to the empirical quantiles of the distribution. If the data are well represented by the Bernoulli/Geometric assumption, a plot of the theoretical quantiles against the empirical quantiles will result in a graph which traces the 45 degree line. However, if there is any sort of clustering across time, especially in the lower quantiles, this will be identified through differences between distributions.

Figure 4: QQ plot test for randomness of crises occurence
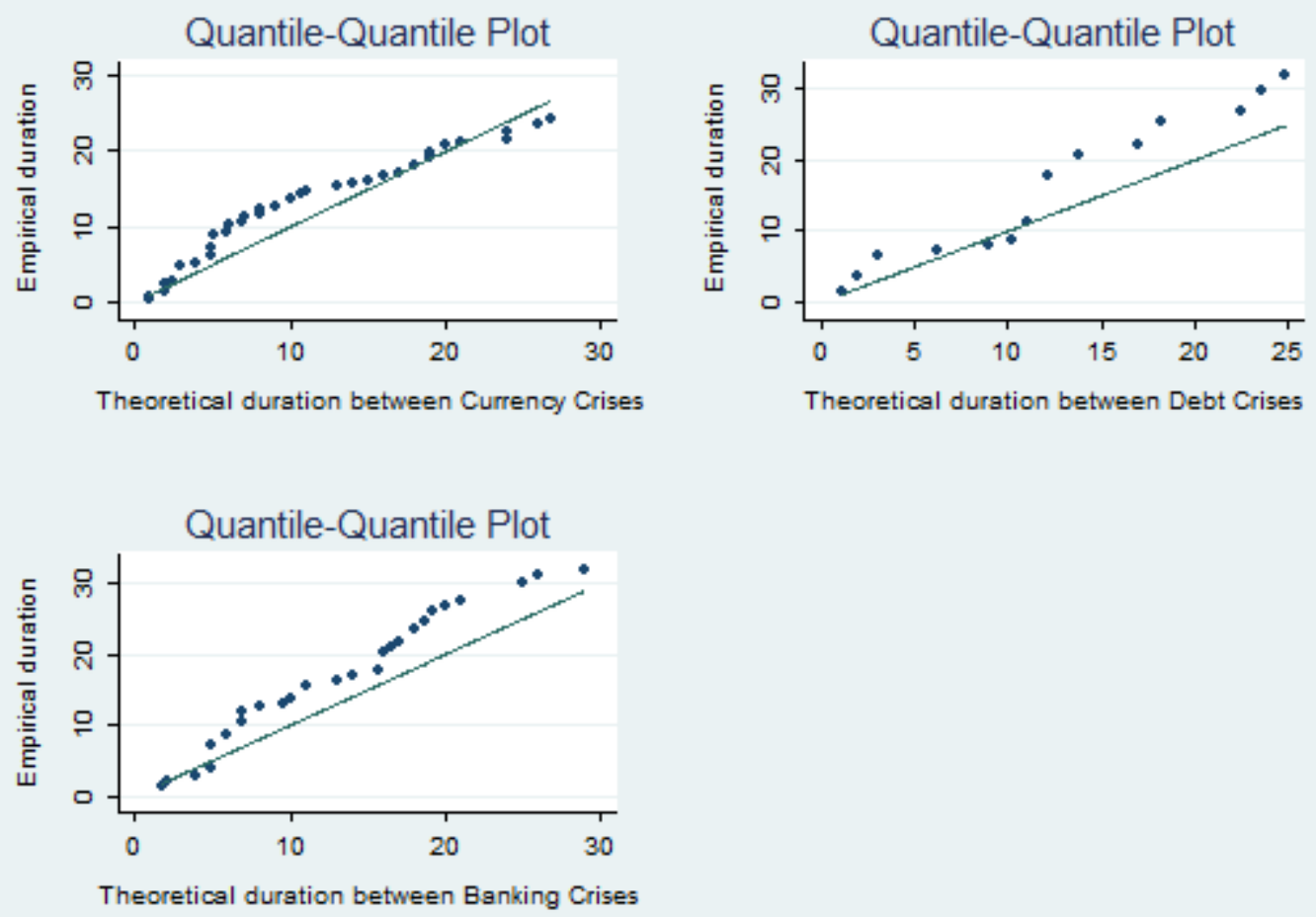

${ }^{4}$ Source: Authors' calculations

As can be seen in the Figure 4 for currency, debt and banking crises, the empirical distribution deviates from the 45 degree line. We can consequently conclude that the occurrence of currency and debt crises cannot be represented as a "fully" random process. In addition, according to the kernel density of banking crises, we think that the deviation from the benchmark line is probably 
due to the presence of outliers in the distribution (or an over-dispersion in the distribution). These results provide us with a justification for using a model which uses a pooled sample of durations for each crisis rather than a model which distinguishes the cross section dimension of our data.

As has been shown above, both tests, the QQ-Plot as well as a visual inspection of the kernel density functions, lead us to the conclusion that the data should be represented by a multi-modal distribution.

The objective of the next section is to show that the model chosen is coherent with the objective to be attained and the data used therefore.

\section{Methodology}

\subsection{The Finite Mixture Model}

The extent and the potential for applications of finite mixture models (FMM) have widened considerably during the past decade. Initially, FMM models have been used in medical studies with different subgroups of patients. Because of their flexibility, mixture models are being increasingly exploited as a convenient, semi-parametric way in which to model unknown distributional shapes. Finite mixture models provide great flexibility in fitting models with many modes, skewness and non-standard distributional characteristics. Other recent developments covered include the use of mixture models for handling over dispersion in generalized linear models and are proposed for dealing with mixed continuous and categorical variables. In some instances, components are introduced into the mixture model to allow for greater flexibility in modeling a heterogeneous population which can not be modeled by a single component distribution.

In comparison with techniques relying on visual identification, one of the advantages of finite mixture models is that this framework permits to avoid spurious identification of clusters in data. Indeed, bimodality in a given histogram of featured data is suggestive of the possibility that the data have been drawn from a mixture distribution. However, bimodality (or a linear combinations of the data if multivariate) does not always imply that the data have been sampled from a mixture distribution ${ }^{5}$. This problem can be avoided by applying FMM models.

\footnotetext{
${ }^{5}$ This point was illustrated in the seminal paper of Day (1969) on normal mixture models
} 
The main limit of Finite Mixture Models is related to the difficulty to distinguish between inherently skewed distributions and mixtures ${ }^{6}$.

\section{- Formulation of Finite Mixture Models}

Let $D_{1} ; D_{2} ; \ldots ; D_{n}$ be an identically distributed p-dimensional observation from a distribution with probability density function :

$$
f(d ; \pi)=\sum_{k=1}^{K} \pi_{k} f_{k}(d)
$$

where $\pi_{k}$ is the $k^{t h}$ mixing proportion which represents the probability that the observation $D_{i}$ belongs to the $k^{t h}$ subpopulation with corresponding density $f_{k}(d)$, called the $k^{t h}$ mixing or component density. Here, K represents the total number of components with $\pi=\left(\pi_{1}, \pi_{2}, \ldots, \pi_{K}\right)^{\prime}$ lying in the $(K-1)$-dimensional simplex, i.e. $0 \leq \pi_{k} \leq 1, \forall k=1,2, \ldots, K$ and $\sum_{k=1}^{K} \pi_{k}=1$.

Usually $f_{k}$ 's are assumed to be of parametric form i.e. $f_{k}(d) \equiv f_{k}\left(d \mid x, v_{k}\right)$, where the functional form of $f_{k}(. ;$.$) is completely known, except for the parameterizing vector v_{k}$. One of the innovations in this paper is that we also parameterize the probability for observation i to belong to component $\mathrm{k}$, given its characteristics $Z_{i}$, as follows:

$$
\pi_{k}\left(d \mid Z_{i} ; \psi_{k}\right)=\frac{\exp \left(Z_{i} \psi_{k}\right)}{\exp \left(Z_{i} \psi_{1}\right)+\exp \left(Z_{i} \psi_{2}\right)+\ldots+\exp \left(Z_{i} \psi_{k-1}\right)+1}
$$

Consequently, the finite mixture model density can be formulated as follows:

$$
f(d \mid x, Z ; v, \psi)=\sum_{k=1}^{K} \pi\left(d \mid Z ; \psi_{k-1}\right) f_{k}\left(d \mid x ; v_{k}\right)
$$

Thus, mixture models can be viewed as a semi parametric compromise between a fully parametric model, represented by a single parametric family $(\mathrm{k}=1)$ and a fully nonparametric model, as represented in the case $\mathrm{k}=\mathrm{K}$ by the kernel method of density estimation. ${ }^{4}$ Therefore, Fi-

\footnotetext{
6 "How [we are] to discriminate between a true curve of skew type and a compound [that is, a mixture] curve, supposing we have no reason to suspect our statistics a priori of mixture. I have at present been able to find any general condition among moments, which would be impossible for a skew curve and possible for a compound, and so indicate compoundness. I do not, however, despair of one being found" Pearson (1895, P. 394)

${ }^{4}$ For Jordan and $\mathrm{Xu}$ (1995), mixture model-based approaches are parametric in the sense that parametric components are specified in the density functions, but they can also be regarded as nonparametric by allowing the number of components $\mathrm{k}$ to grow
} 
nite Mixture Models have a large variety of nonparametric approaches, while retaining some of the advantages of parametric approaches, such as keeping the dimension of the parameter space down to a reasonable size.

In this paper, we rely on the visualization of the kernel density and on the conclusion of the QQ plot test to set the number of components to $K=2$. The price for this flexibility is an increase in the number of parameters with the number of components $f_{k}$. Indeed, rather than estimating one set of parameters, three subsets of parameters are estimated. These are: $v_{1}, v_{2}$ and $\psi_{1}$, which are the parameters associated with the contribution of each covariant $\mathrm{X}$ respectively to the density of component 1 , component 2 and the relative contribution of each covariant $\mathrm{Z}$ to the probability of belonging to component 1 . The second implication associated with our choice of $\mathrm{k}=2$ is that specification (5), representing the probability of belonging to component one, is a simple logit model.

\section{- Likelihood Maximization via the EM Algorithm}

The estimation of finite mixture models is carried out using an Expectation-Maximization algorithm (EM). The EM algorithm is an iterative (a succession of expectations and maximization steps), strictly hill-climbing procedure whose performance can depend severely on particular starting points since the likelihood function often depicts numerous local maxima. Many different initialization procedures have been suggested in the literature but no method uniformly outperforms all others. In this paper, the starting values of group weights are set to equal observed empirical frequencies.

\section{- Marginal effects and interpretation of parameters}

The interpretation of finite mixture model parameters is not straightforward. To simplify understanding, let us consider the conditional mean of duration obtained from FMM:

$$
E\left(d_{i} \mid X_{i}, Z_{i}\right)=\sum_{k=1}^{2} \pi_{k} \lambda_{k} \text { with } \lambda_{k}=E_{k}\left(d_{i} \mid X_{i}, Z_{i}\right)
$$

The parameters $v_{k}$ represent the marginal effect of $X_{i}$ on the within variability of duration in each component $\mathrm{k}$, and are given by: $v_{k}=\frac{\partial E_{k}\left(d_{i} \mid X_{i}, Z_{i}\right)}{\partial X_{i}}$. The parameters $\psi_{k}$ represent the 
marginal effect of each concomitant variable $Z_{i}$ on the probability of belonging to the component k. Hence, the model allows capturing both the variability within and between the groups.

As can be seen graphically in Appendix:Figure 8, the interpretation of the model is as follows: A positive coefficient $v_{1}$ in component one means that the duration between crises within the first group increases. Equally, a positive coefficient $v_{2}$ in component 2 shows an increase in the period of stability within the second group of observations. A positive coefficient $\psi_{1}$ reflects a heightened probability of belonging to group one.

It is possible that the three coefficients of the same variable appear with opposite signs and different levels of significance for the two components and the probability, since estimations may follow different dynamics between and across subgroups.

\subsection{Choice and computation of covariants}

Our framework of analysis for the duration of stability periods involves a specific treatment for covariants X and Z. The transformations adopted are motivated by the fact that our dependent variable is constant for every year regressed upon. An additional motivation is that many economic time series occasionally exhibit dramatic breaks in their behavior associated with events such as financial crises (Jeanne and Masson (2002), Cerra (2005) and Hamilton (2005)). For this purpose, we need to distinguish the period of relative stability from the period during which the potential break occurs before a financial crisis. Our strategy consists of defining two kinds of transformations for covariants. We split the stability period between two crises into two subperiods: a period until three years before occurrence of a financial crisis and a period covering the three years preceding a crisis ending a period of stability.

Subsequently, we compute a deviation from a linear trend for the first period, and a geometric growth rate of each covariant for the second period:

$$
\bar{X}_{\text {TRENDdev }}=\frac{1}{N} \sum_{t=t^{\prime}}^{T^{\prime}=t^{\prime}+d-3=T-3}[X-(\hat{\alpha}+\hat{\beta} t)] \text { and } X_{G R O W T H 3}=\left[\left(\frac{X_{T}}{X_{T-3}}\right)^{\frac{1}{3}}\right]-1
$$

Where $\mathrm{t}$ ' is the date of current crisis and $\mathrm{T}$ is the date of the next crisis.

Each variable enters the model twice for each component and for the determination of the 
probability. Each time, the coefficients can be interpreted as the long term and short term factors influencing the duration of a period of stability. We do not consider the deviation from trend variable for component one, as it would be a trend calculated over two years in the case of 5 year stability periods.

Figure 5: Illustration

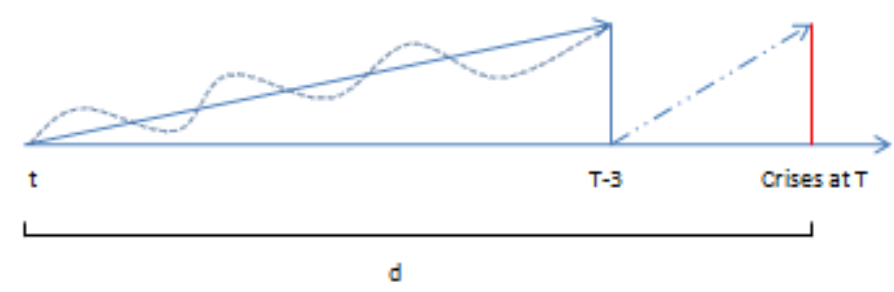

\section{Estimation}

\subsection{Small sample issue: Bootstrap simulations}

While the number of observations is "sufficient" to perform the FMM model for currency crises, the low frequency of debt crises makes estimations of the latter less reliable. A solution to treat this small sample issue is to use the nonparametric bootstrap method, a simulation technique consisting of re-estimating iteratively the FMM parameters for randomly drawn samples ${ }^{7}$. B sub samples of $\mathrm{K}$ length are extracted with replacement from the original sample, and estimations yield a vector $\hat{\theta}$ of parameters; with $\hat{\theta}=(\hat{\psi}, \hat{v})$ We set $B=1000$.

From these bootstrap estimates an indicator "p" is built as the ratio of the number of estimates within a confidence interval at 0.95 (i.e. statistically significant at $5 \%$ ) to the number of total re-samplings. A high score of "p" suggests that for a large share of the re-samplings the results are robust.

In the next subsection, we use bootstrap simulations as robust results for debt crises parameters and as robustness tests for the currency crises parameters obtained from the initial sample.

\footnotetext{
${ }^{7}$ The advantage of this technique is its simplicity, its applicability to a wide range of nonlinear models, and its reliance on weak distributional assumptions.
} 


\subsection{Results}

Estimations are carried out using three groups of explanatory variables: Real variables, financial and monetary variables, as well as equilibrium or long-term variables.

\subsubsection{Currency crises}

- Real Variables

Within the group of real variables (Investment, the real interest rate, and GDP per capita), the coefficients of investment growth and GDP growth 3 years before a crises are positive and significant in component one. This means that high GDP and investment growth in the three years prior to a crisis tend to postpone potential financial crises conditional on the observation belonging to the group of relatively short stability periods of around five years. As investment after financial crises is observed to recover within a period of three to seven years, we believe that the positive coefficient captures the recovery process rather than a boom-bust development. It is assumed that economic recovery after financial crises depends crucially on investment recovery. If thus investment picks up sufficiently strong, less of an incentive exists to recover growth through a devaluation/depreciation of the exchange rate.

In the same line, a prolonging effect on the duration of stability can be observed in component two(Stability periods around 15 years).

In the wake of capital flights and/or speculative attacks, a country can follow three possible courses of action. It can either decide to sell foreign currency reserves in order to support its currency, it can increase its remuneration to capital by raising interest rates and hoping to attract foreign capital, or in the last case accept the depreciation. In our sample, an increase in the real interest rate decreases the duration of stability periods on both components. A hike of the interest rate before a currency crises seems to have been a frequently adopted, however often unsuccessful measure.

While the results obtained regarding GDP growth are in line with the conclusions drawn by e.g. Kaminsky and Reinhart (1999), who find that currency crises are generally preceded by negative GDP growth ${ }^{8}$, the fact that real interest rate hikes are correlated with shorter durations

\footnotetext{
${ }^{8}$ As Kaminsky and Reinhart consider a time window of 18 month before and after financial crises, their results can be compared with the results presented above regarding average growth of variables three years prior to a
} 
of stability does not coincide with their results. The predominance of currency crises during the 1970's in their sample could explain this difference ${ }^{9}$.

Table 1: Finite mixture model for Currency crises : Real Variables

\begin{tabular}{|c|c|c|c|c|c|c|}
\hline \multirow[b]{2}{*}{ VARIABLES } & \multicolumn{3}{|c|}{ Real Variables:Baseline } & \multicolumn{3}{|c|}{ Real Variables:Augmented } \\
\hline & component1 & component2 & imlogitpi1 & component1 & component2 & imlogitpi1 \\
\hline $\operatorname{nir}_{G}$ rowth3 & $\begin{array}{l}1.957^{* * *} \\
(0.725)\end{array}$ & $\begin{array}{l}-0.408 \\
(3.219)\end{array}$ & $\begin{array}{l}1.577 \\
(1.392)\end{array}$ & $\begin{array}{l}-0.831^{* * *} \\
(0.0858)\end{array}$ & $\begin{array}{c}-5.348^{*} \\
(3.112)\end{array}$ & $\begin{array}{l}132.4 \\
(45,287)\end{array}$ \\
\hline $\operatorname{mnir}_{T R E N D d e v}$ & & $\begin{array}{l}0 \\
(0)\end{array}$ & $\begin{array}{l}0 \\
(0)\end{array}$ & & $\begin{array}{l}0^{*} \\
(0)\end{array}$ & $\begin{array}{l}0 \\
(4.8 \mathrm{e}-09)\end{array}$ \\
\hline $\operatorname{gdppercap}_{G}$ rowth 3 & $\begin{array}{l}5.889^{* * *} \\
(1.788)\end{array}$ & $\begin{array}{l}4.715 \\
(4.859)\end{array}$ & $\begin{array}{l}1.147 \\
(2.225)\end{array}$ & $\begin{array}{l}4.535^{* * *} \\
(0.140)\end{array}$ & $\begin{array}{l}22.81^{* * *} \\
(6.868)\end{array}$ & $\begin{array}{l}106.5 \\
(63,238)\end{array}$ \\
\hline $\operatorname{gdppercap}_{T R E N D d e v}$ & & $\begin{array}{l}0.0001 \\
(7.6 \mathrm{e}-05)\end{array}$ & $\begin{array}{l}2.7 \mathrm{e}-05 \\
(2.8 \mathrm{e}-05)\end{array}$ & & $\begin{array}{l}0.0002^{* * *} \\
(6.1 \mathrm{e}-05)\end{array}$ & $\begin{array}{c}-0.0056 \\
(1.726)\end{array}$ \\
\hline Realinterest $_{G}$ rowth 3 & & & & $\begin{array}{l}-2.546^{* * *} \\
(0.0627)\end{array}$ & $\begin{array}{l}-7.814^{* * *} \\
(1.646)\end{array}$ & $\begin{array}{l}-71.23 \\
(49,060)\end{array}$ \\
\hline Realinterest $_{T R E N D d e v}$ & & & & & $\begin{array}{l}-0.0424 \\
(0.0490)\end{array}$ & $\begin{array}{l}-9.088 \\
(1,057)\end{array}$ \\
\hline Constant & $\begin{array}{l}5.428^{* * *} \\
(0.153)\end{array}$ & $\begin{array}{l}13.99^{* * *} \\
(0.638)\end{array}$ & $\begin{array}{c}-0.0336 \\
(0.238)\end{array}$ & $\begin{array}{l}8.572^{* * *} \\
(0.0501)\end{array}$ & $\begin{array}{l}17.36^{* * *} \\
(2.898)\end{array}$ & $\begin{array}{l}-18.60 \\
(42,665)\end{array}$ \\
\hline lnsigma & $\begin{array}{l}-0.125 \\
(0.140)\end{array}$ & $\begin{array}{l}1.250^{* * *} \\
(0.131)\end{array}$ & & $\begin{array}{l}-4.015^{* * *} \\
(0.250)\end{array}$ & $\begin{array}{l}0.946^{* * *} \\
(0.141)\end{array}$ & \\
\hline Observations & 102 & 102 & 102 & 33 & 33 & 33 \\
\hline
\end{tabular}

- Financial and monetary variables

The ratio of M2 over reserves can be interpreted as a measure of the vulnerability towards a speculative attack. M2 is the quantity of money that can be exchanged, while foreign exchange reserves are the means which a Central bank can use to defend the currency in the case of a speculative attack. An increase in the ratio has a decreasing effect on the duration between crises in component two. One reason being that reserves often have been decreased substantially in order to fight off speculative attacks, which at some point has diminished reserves sufficiently to render the attack successful. On the other hand, the ratio represents the extend to which the economy is supported by monetary easing. Often enough, this policy is adopted during years preceding a crisis.

crisis.

${ }^{9}$ In the 1970's, interest rates were highly regulated and therefore not particularly informative as leading financial crises indicators. 
The result concerning the behavior of the ratio of M2 over reserves before financial crises is confirmed by Sachs et al. (1996), as well as by Kaminsky and Reinhart (1999). In addition, Kaminsky and Reinhart (1999) find that prior to currency crises, the ratio of M2 over reserves increases due to both, monetary easing and a decrease in international reserves.

The ratio of Credit over GDP is only significant for the deviation from trend in component two, representing long durations of stability, and shows a positive sign. The growth rate of credit over gdp for the three years before a crisis depicts a negative sign, is however not significant. Since the Fisher test rejects the null for joint insignificance, we can interpret both results.

As observed by Sachs et al. (1996) and by Kaminsky and Reinhart (1996), the growth rate of the ratio three years before a crisis depicts a certain boom and bust development. Moreover, the deviation from trend can be interpreted as a reflection of the progress of recovery.

Net foreign assets are the difference between foreign assets held by residents and domestic assets held by foreigners. An increase in net foreign assets decreases the possibility of a sudden stop as the country is or becomes a net creditor. The coefficient in component two is consequently positive and significant for both, the deviation from trend and the growth of net foreign assets three years before a crisis. Unexpectedly, the probability coefficient shows a positive sign. Shorter durations of stability are therefore related to larger growth of net foreign assets during the three years before the onset of a crises.

- Equilibrium (External) variables

The negative sign in component two for short term increases in the current account is negative and significant. We suspect that the relative position of countries compared to the balance of the current account matters. In order to evaluate this suspicion, we re-estimate the model including the fact that a country depicts a positive or negative current account. We introduce a dummy variable in the specification for countries which have a negative current account balance and an interactive term, which captures the heterogeneity in the impact of the current account. By doing so, the current account loses its significance. Due to this observation, we will focus on the development of the real exchange rate and the terms of trade in order to capture drivers of the current account instead of the current account itself. 
The real exchange rate captures two effects. The first one reflects the evolution of the nominal exchange rate, the second captures the development of the internal price level compared to the external price level of the 10 countries constituting the reference group. An increase in the real exchange rate implies a real depreciation. Our results show that a depreciation in the three years before a crisis increases the probability to belong to group one. As the variable is constructed over a three year period, the nominal exchange rate effect is likely to dominate the price effect. Therefore we probably capture an effect in line with the second generation of self fulfilling crises models. Constant depreciation, possibly coupled with self-reinforcing speculative attacks, are observed prior to the actual currency crisis. The often mentioned long term real appreciation before currency crises cannot be confirmed by our model as the coefficients for the deviation from trend are not significant.

Terms of trade are calculated as the ratio between prices of export goods and import goods of a given country. In our model, increasing terms of trade have a stabilizing effect for both groups of durations in the short- and in the long-run. Positive deviations from trend for a prolonged period of time increase the probability to belong to the second group of observations. Thus, an increase in terms of trade increases the duration between currency crises, consistent with the finding of Kaminsky and Reinhart (1996). The interpretation of these results is straightforward. Intuitively, it is beneficial for a country if the goods it exports achieve higher prices on world markets and the goods that are imported are as cheap as possible. As small countries have little possibility to influence international prices, a positive growth of this ratio leads to less of a need to depreciate the exchange rate in order to regain competitiveness.

The bootstrap simulations confirm these results for all coefficients except for the coefficient of real interest rate growth in the probability (Annex: Table 13, 14 and 15 ). 


\subsubsection{Debt crises}

The limited number of observations with respect to the parameters chosen leads us to consider separate specifications for each concomitant variable. Furthermore, we dropped variables for which the iterative EM did not converge.

- Real Variables

For debt crises, it is interesting to compare the impact of our concomitant variables with the macroeconomic indicators used by rating agencies to assess a country's probability of default. Some of the most decisive factors determining a credit rating are usually the GDP per capita, GDP growth, the current account, and the interest rate.

Higher GDP growth has a prolonging effect on the duration of stability periods. Indeed, the coefficients of component 1 and component 2 are positive, while the coefficient of the probability is negative. This suggests that higher GDP growth increases the spell of time between two debt crises and increases the probability to belong to the group of observations experiencing long periods of stability between debt crises. These results are consistent with the debt sustainability literature.

As stated by Canuto et al (2004), governments of high per capita income countries typically possess a low risk assessment. Per capita income is normally regarded as a good indicator of the general level of economic and institutional development of a particular country. Rich countries' governments have a larger flexibility to adopt tight policies in adverse periods.

The rating agency Moody's (2003) asserts the relevance of a given range of variables according to the level of a country's development. Most rating agencies (see Fitch, 1998, Moody's, 2003) reason that authorities in developed countries with a long history of economic and institutional stability possess better instruments for managing public debts, high fiscal deficits and unexpected economic shocks. The results obtained confirm the general logic followed by these rating agencies. The richer a country, the higher the probability that the duration between debt crises is large (the observation belongs to component two $)^{10}$.

\footnotetext{
${ }^{10}$ High income is thus important to forego crises given that a default occurs relatively frequent. Once a country has proven to default sufficiently seldom, the income level effect vanishes.
} 
Table 2: Simulation : GDP per Capita growth

\begin{tabular}{lccc}
\hline & Signif. initial FMM & Coef. & $\mathrm{p}$ \\
\hline component1 & $* * *$ & $26.31^{* * *}$ & .87887888 \\
& & $(6.561)$ & \\
component2 & 6.930 & .88188188 \\
& & $(16.38)$ & \\
imlogitpi1 & -2.974 & .92692693 \\
& & $(10.75)$ & \\
\hline
\end{tabular}

Table 3: Simulation : GDP per Capita level

\begin{tabular}{lccc}
\hline & Signif. initial FMM & Coef. & $\mathrm{p}$ \\
\hline component1 & & $-6.08 \mathrm{e}-05$ & .925 \\
& $* *$ & $(0.000359)$ & \\
component2 & & -0.000323 & .873 \\
& $*$ & $(0.000249)$ & \\
imlogitpi1 & $*$ & -0.000167 & .776 \\
& & $(0.000355)$ & \\
\hline
\end{tabular}

- Financial and monetary variables

High growth of the ratio of credit over GDP prolongs stability periods for both groups of observations. For component one, the basis of calculation for the coefficient covers nearly the whole period of recovery. Its positive sign reflects the ability of credit to recover after debt crises and it is equally an indicator of confidence. Within component two, high credit over GDP growth leads to increased length of stability periods. According to Canuto et al. (2004), the domestic credit available as a percentage of GDP is a good indicator for the level of financial development. In general, the issuers of countries with high credit to gdp ratios receive better ratings. The statistical quality of these results is assessed through the "p" indicator, suggesting high statistical significance the closer the indicator is to one. The "p" indicator for the growth rate of credit over GDP in the probability is quite low ( it indicates that only $63 \%$ of re-sampling coefficients are inside an interval confidence at 5\%), rendering interpretation little reliable. 
Table 4: Simulation : Credit over GDP growth

\begin{tabular}{lccc}
\hline & Signif. initial FMM & Coef. & $\mathrm{p}$ \\
\hline component1 & $* * *$ & 8.379 & .81039755 \\
& & $(5.301)$ & \\
component2 & 8.286 & .86340469 \\
& & $(12.77)$ & \\
imlogitpi1 & 1.456 & .63098879 \\
& & $(6.277)$ & \\
\hline
\end{tabular}

- Equilibrium (External) variables

In general, one would expect a positive growth of the current account over GDP and an increase in the level of the current account (measured by the growth of net foreign assets) to enhance the length of stability periods for both components ${ }^{11}$. Kaminsky and Reinhart (1999) show however that the behavior of the current account balance during the 18 months preceding twin crises does not matter. Our results are consistent with their findings ${ }^{12}$.

A positive external shock on a country's terms of trade can render a deficit more sustainable and ameliorate anticipations of foreign investors about the ability of a country to repay its debt. This leads to a consequent increase of capital flows towards the country. The results presented in table 9 suggest indeed that an improvement in the terms of trade increases stability periods for both groups of observations ${ }^{13}$.

Table 5: Simulation : Current Account balance over GDP

\begin{tabular}{lccc}
\hline & Signif. initial FMM & Coef. & $\mathrm{p}$ \\
\hline component1 & & -0.691 & .62134945 \\
& $*$ & $(2.868)$ & \\
component2 & & -5.937 & .89224572 \\
& & $(3.783)$ & \\
imlogitpi1 & 0.0933 & .89325277 \\
& & $(23.23)$ & \\
\hline
\end{tabular}

\footnotetext{
${ }^{11}$ Hence, an improvement of the external debt position of a country reduces the risk to experience a default.

${ }^{12}$ An alternative explanation could be that the GDP dynamics dominate the dynamics of the current account. In addition, Kaminsky et al. state that it is the composition of capital inflows rather than the current account balance itself which matters.

${ }^{13}$ The low "p" value from the bootstrap simulations carried out makes results less reliable. In the same line, we observe a counterintuitive increase in the probability of an observation to belong to the first group of observations in the case of a positive shock to terms of trade.
} 
Table 6: Simulation : Terms of trade

\begin{tabular}{lccc}
\hline & Signif. initial FMM & Coef. & $\mathrm{p}$ \\
\hline component1 & $* * *$ & 12.30 & .65993946 \\
& & $(6.694)$ & \\
component2 & $*$ & 34.82 & .71745711 \\
& & $(30.19)$ & \\
imlogitpi1 & $* *$ & 23.75 & .88597376 \\
& & $(20.11)$ & \\
& & &
\end{tabular}

\subsubsection{Predictive quality Analysis}

The task of assessing model fit is not straightforward for mixture models, at least not for multivariate data. Two strategies are proposed in the literature. For univariate data, the goodness of FMM predictions can be tested by comparing the fitted mixture density with the data in histogram form. Alternatively, Aitkin (1997) advocates a comparison of the fitted mixture distribution function with the empirical distribution. In this sub-section, we choose to evaluate the predictive quality of each group of independent variables by using the second option.

As shown in Figure 6, the FMM model predicts durations between currency crises fairly well. Clear differences between the three groups of variables exist. Globally, real variables have the highest predictive power for the countries experiencing currency crises frequently. The second group of countries is better represented through usage of financial variables. Equilibrium variables lead to an over fitting of the distribution for both groups ${ }^{14}$.

Table 7: Predictive quality: AIC Information Criterion

\begin{tabular}{lcccc}
\hline \multirow{2}{*}{ SPECIFICATION } & \multicolumn{2}{c}{ REAL } & \multirow{2}{*}{ FIN. and MONETARY } & EQUILIBRIUM \\
\cline { 2 - 3 } & OTHERS & REAL INTEREST RATE & & \\
\hline CURRENCY CRISIS & 139.4587 & - & 468.1525 & 396.8343 \\
DEBT CRISIS & 100.4615 & 73.83928 & 95.65441 & 85.47905 \\
\hline
\end{tabular}

Turning towards debt crises, it is somewhat astounding that the real interest rate is the best

\footnotetext{
${ }^{14}$ For group one, it makes intuitive sense that the variables chosen lead to over fitting, since nearly all variables within this group do not exhibit large variability over the short term. For the second group, over fitting is smaller than for group one if second order stochastic dominance is taken into account.
} 
predictor. According to the AIC information criteria, the real interest rate predicts the duration between debt crises slightly better than equilibrium variables, which in turn predict better than financial variables. Real variables without the real interest rate depict serious under fitting.

Figure 6: Predictive quality of FMM specification : Currency crises
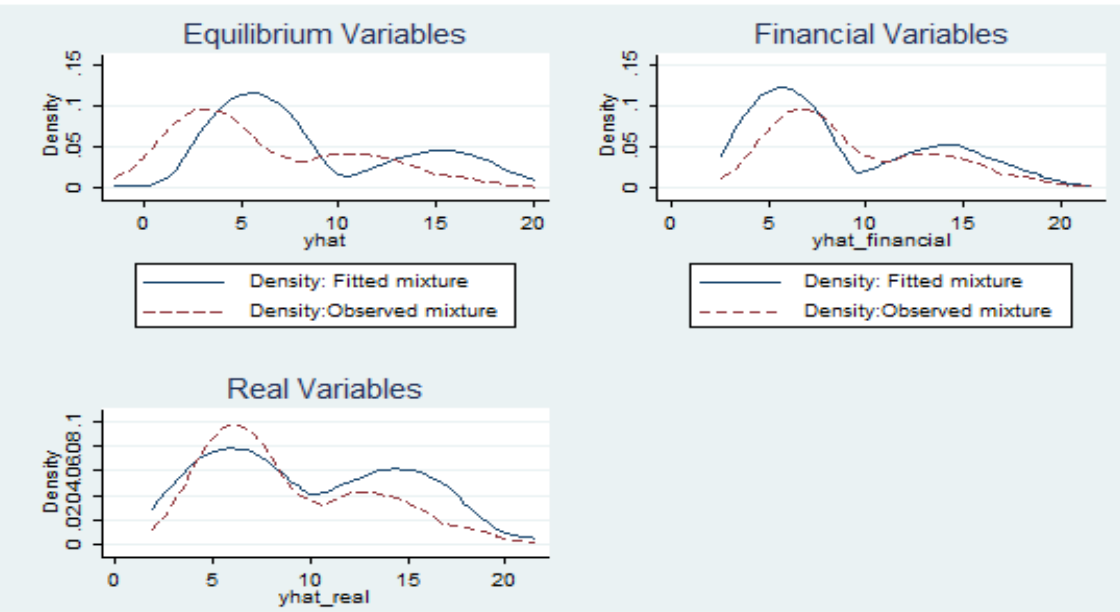

Source: Authors' calculations

Figure 7: Predictive quality of FMM specification : Debt crises

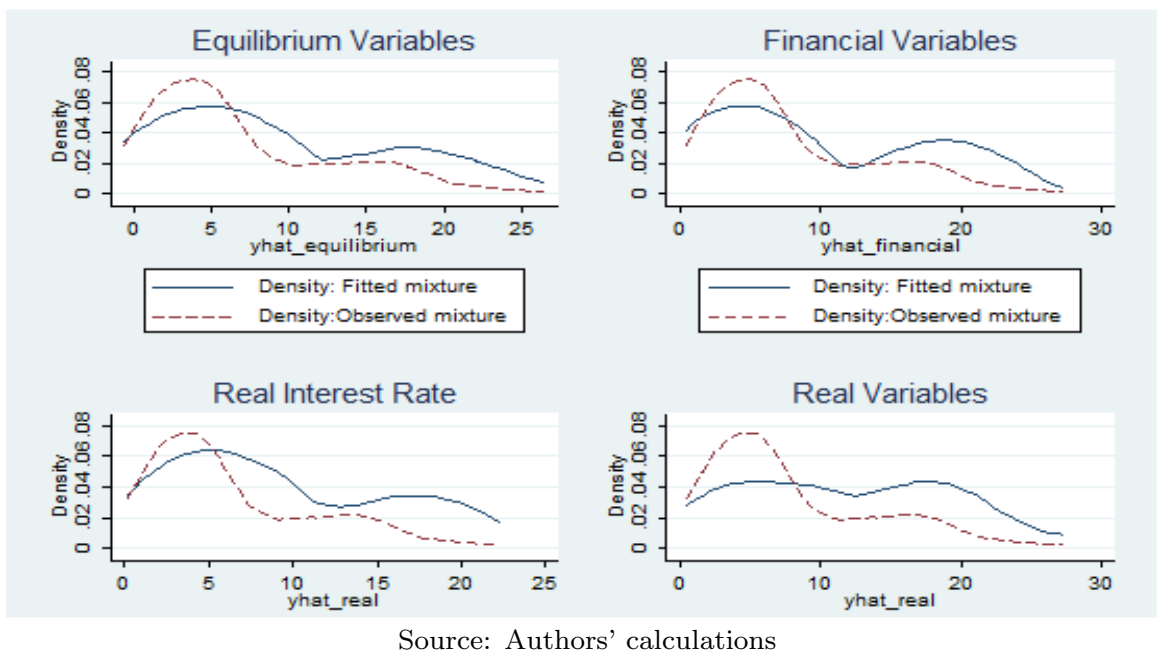




\section{Policy recommendations after systemic financial crises}

In this section we analyze the duration of stability periods after systemic crises, defined as a banking crisis preceded or followed either by a currency or a debt crisis, or in the most extreme case the occurrence of all three types of crises within a period of 5 years.

Cerra and Saxena (2008) and Kaminsky and Reinhart (1999) show that twin crises and systemic crises are most harmful in terms of output loss and time of recovery. Hence, a challenging task for policymakers is to implement measures that alleviate financial strains and restore credit functioning, but to avoid planting the seeds for a next crisis. In order to assess the impact of macroeconomic and microeconomic policies in the period after a systemic crisis, we use indicators as provided by the IMF systemic banking crisis resolution database (Leaven and Valencia (2008)). The explanatory variables are divided in three groups: macroeconomic policies, containment measures and resolution measures.

Macroeconomic policies are the average change in reserve money and average fiscal balances during the first three years after a systemic crisis and a dummy variable if an IMF program was put in place.

Containment measures are the immediate policy responses to liquidity stress in the early stage of a financial crisis. We consider a dummy variable depicting if reserve requirements were lowered to sustain the money multiplier and the maximum of liquidity support in percentage of deposits that monetary authorities accorded to banks.

Resolution measures are the medium term policies adopted to restructure borrowers and lenders' balance sheets and to restore bank functionality. This is a critical task. On the one hand, a country restoring a sounder credit system is supposed to recover faster. On the other hand, these operations imply high fiscal costs and may foster moral hazard. We also consider if the government interferes with bank management using systemic interventions (like recapitalization nationalizations, closures, mergers, and sales), and more specifically the gross recapitalization costs to governments as a percentage of GDP. We also include a dummy variable if a deposit insurance scheme was in place at the start of a banking crisis and 2 dummy variables for regulatory forbearance in the case that banks were permitted to function, although technically insolvent, and whether prudential regulations were suspended or not fully applied. 
As the distribution of the duration of stability after systemic banking crises turns out to be not bimodal, we used OLS techniques to assess the impact of the three distinct groups of policy variables. Tables 8 and 9 display the results.

Table 11. indicates that the countries which adopt an IMF program during and/or after systemic banking crisis experience longer stability periods.

Turning towards fiscal and monetary policy, results point towards the fact that expansionary monetary policy put into place during the first three years after a crisis reduces the duration of stability. This result should be treated with caution. A possibility exists that the result is influenced through imperfect measurement of the monetary policy index. Firstly, the measure does not capture some aspects of monetary policy such as the management of interest rates. Secondly, our index of systemic banking crisis corresponds to a banking crisis which is followed by a currency crisis and /or a debt crisis. Therefore, when a currency crisis occurs one year after a banking crisis, the variation of reserves may simply reflect the reaction of the central bank attempting to sustain its currency and trying to avoid a currency crisis.

Regarding fiscal policy, we find that an expansionary fiscal policy during the first three years after a systemic banking crisis has no effect on the duration of the length of the stability period. Following this finding, it would be interesting to divide the sample of systemic crises into banking crises followed by currency crises and banking crises followed by debt crises. In fact, the effect of "crisis contingent-fiscal policy" measures may depend on other factors such as initial macroeconomic conditions (e.g. the initial level of fiscal deficit) ${ }^{15}$.

The first two columns of Table 9 show the results for the assessment of the impact of immediate measures adopted by the governments to contain the impact of a crisis. Column two indicates that the duration of stability periods after a systemic crisis decreases with the level of the maximum of liquidity support in percentage of deposit that monetary authorities accorded to banks. It is however not influenced by the reduction of reserve requirements in the three years following a crisis.

Once emergency measures have been put into place to contain a crisis, the government faces

\footnotetext{
${ }^{15}$ The role of fiscal policy on the process of recovery after financial crises is an open debate in macroeconomics. On one hand, Keynesian theory suggests that government spending could push private demand and the economic production. On the other hand, the New Classicals' viewpoint expresses that public expenditure could restore confidence of investors, therefore lowering the risk premium, emitting a positive effect on economic activity even in the short term.
} 
the long-run challenge of crisis resolution, which entails the resumption of a normally functioning credit and legal system, and the rebuilding of banks' and borrowers' balance sheets. Columns 3 and 4 of Table 9 show the impact of an adoption of these measures on the stability period after a given crisis.

On the one hand, it seems that only large-scale government interventions in banks, such as nationalizations, closures, mergers, sales, and re-capitalizations of large banks have a positive impact on the duration of stability periods.

On the other hand, the results indicate that a recapitalization ${ }^{16}$ has a reducing effect on the length of stability periods after a systemic banking crisis. This result can be explained following two arguments. The first one focuses on the inherent information asymmetry according to which recapitalization could result in an increase of moral hazard. Indeed, when a recapitalization is put in place, it is very unlikely that the creditors incur losses, unless the recapitalization fails and the firm is subsequently put into insolvency. In this case, creditors are bailed out, creating significant moral hazard. In addition, if shareholders are only diluted or receive compensation, this will further exacerbate moral hazard by socializing the losses. ${ }^{17}$ Beyond this, Claessens et al. (2011) noted that public re-capitalizations, by aiming to have a rapid effect, avoid stigmatization and support lending. On the down side, they may be detrimental in the long run if spread too broadly, thereby foregoing the benefits of separating viable from nonviable institutions.

Another explanation for the lack of impact is related to the nature of the crisis. In fact, when a systemic crisis is a national one, idiosyncratic resolution measures could be efficient. However, if a systemic crisis is global, coordinated actions of concerned countries are more appropriate.

According to the estimations carried out above, one policy recommendation clearly hints towards large-scale government interventions which may help to restore the confidence in banks and to sustain accelerated recovery of the economy. In addition, an adoption of IMF programs during and/or after a systemic banking crisis may help to stabilize the economy (i.e. increase the duration of the stability period after the crisis), but this last solution involves a partial loss of sovereignty of governments.

\footnotetext{
${ }^{16}$ In the form of (1) cash , (2) government bonds, (3) subordinated debt, (4) preferred shares, (5) purchase of bad loans, (6) credit lines, (7) assumption of bank liabilities, or (8) ordinary shares.

${ }^{17}$ The moral hazard argument could also be invoked to explain why other resolution measures (Deposit insurance, Prudential regulation suspended, Bank permitted functioning)have no statistically significant impact on the stability period after a systemic banking crisis.
} 
Table 8: Macro Policy Index

\begin{tabular}{ll}
\hline VARIABLES & $(1)$ \\
\hline Macro Policy Index & $-0.465^{* * *}$ \\
& $(0.140)$ \\
Fiscal policy Index & -27.93 \\
& $(37.47)$ \\
IMF Program & $5.970^{* *}$ \\
& $(2.376)$ \\
constant & $11.78^{* * *}$ \\
& $(2.078)$ \\
\hline Observations & 35 \\
R-squared & 0.231 \\
\hline
\end{tabular}

Table 9: Containement and Resolutions Measures

\begin{tabular}{|c|c|c|c|c|}
\hline \multirow[b]{2}{*}{ VARIABLES } & \multicolumn{2}{|c|}{ Containement Measures } & \multicolumn{2}{|c|}{ Resolution Measures } \\
\hline & $(1)$ & $(2)$ & $(3)$ & $(4)$ \\
\hline Bank permitted functioning & & & -3.901 & -4.042 \\
\hline & & & $(2.509)$ & $(2.457)$ \\
\hline Prudential regulation suspended & & & $\begin{array}{l}1.597 \\
(2.736)\end{array}$ & $\begin{array}{l}1.605 \\
(2.568)\end{array}$ \\
\hline Gov. Intervention & & & $\begin{array}{l}9.234^{* * *} \\
(2.520\end{array}$ & $\begin{array}{l}10.10^{* * *} \\
(2.502)\end{array}$ \\
\hline Recapitalization & & & $\begin{array}{l}-7.28 * * * \\
(2.050)\end{array}$ & $\begin{array}{l}-5.26^{*} \\
(2.947)\end{array}$ \\
\hline Deposit Insurance & & & 1.532 & $\begin{array}{l}0.870 \\
(2.482)\end{array}$ \\
\hline Low res requirement & $\begin{array}{l}-2.86 \\
(2.367)\end{array}$ & $\begin{array}{l}-2.453 \\
(2.315)\end{array}$ & & \\
\hline Peak support & $\begin{array}{l}-1.939 \\
(1.384)\end{array}$ & $\begin{array}{l}-3.569^{* *} \\
(1.466)\end{array}$ & & \\
\hline IMF program & & $\begin{array}{l}4.600^{* *} \\
(2.217)\end{array}$ & & $\begin{array}{l}3.879 \\
(2.903)\end{array}$ \\
\hline R-squared & 0.054 & 0.150 & 0.246 & 0.307 \\
\hline Observations & 40 & 40 & 37 & 37 \\
\hline
\end{tabular}




\section{Conclusion}

This paper has used an innovative econometric strategy, the Finite Mixture Model, to assess the determinants of the duration between financial crises, the aim having been to identify which factors explain why some countries are more prone to enjoy long durations of stability, while others experience crises in shorter intervals.

To this end, we analyzed the duration of stability periods between currency, debt, and banking crises from 1980 to 2008. The distribution of this variable was found to be bimodal regarding currency and debt crisis and two groups of observations emerged: one depicting average stability periods of around 5 years and a second group experiencing crises roughly each 15 years, while the distribution of the duration between banking crises is unimodal.

After having shown that the distribution of the dependent variable does not allow for traditional estimation methods, the finite mixture model approach has been utilized. The FMM was estimated separately for currency and debt crises including 3 groups of concomitant variables: real variables, financial and monetary variables, as well as equilibrium or external sector variables.

The main findings about spells of stability between currency crises were that high GDP and investment growth in the three years prior to a currency crises tend to postpone potential crises conditional on the observation belonging to the group of relatively short stability periods of five years.

An increase in the real interest rate during the three years prior to a crisis decreases the duration of stability periods within both components. An interest rate increase before a currency crises seems to have been a frequently adopted, however often unsuccessful measure.

An increase in the ratio of M2 over reserves has a decreasing effect on the duration between currency crises given that an observation belongs to the group of observations experiencing long stability periods, while an accumulation of net foreign assets does prove to be an effective mean to prolong stability periods for all groups of observations and during all points in time. Sustained credit growth during the stability period postpones potential currency crises, while a certain boom and bust behavior in cases of high credit growth can be confirmed. Regarding the real exchange rate, we capture an effect in line with the second generation of self fulfilling crises 
models. Constant depreciation, possibly coupled with self-reinforcing speculative attacks, are observed prior to the actual currency crisis. The often mentioned long term real appreciation before currency crises cannot be confirmed by our model.

Due to a limited sample size we confirmed our results with the help of bootstrap estimations for currency crises and considered separate specifications for each concomitant variable for debt crises. We found that our results are consistent with the debt sustainability literature and that the main country characteristics usually considered by rating agencies in order to classify sovereign default risk are statistically significant in explaining the length of stability periods between debt crises.

We assessed model fit by comparing the fitted mixture distribution function with the empirical distribution and found that the FMM model predicts durations between financial crises fairly well.

We studied the impact of macroeconomic policies, containment measures, and resolution measures on the duration of stability periods after systemic crises. We found that an expansionary fiscal policy during the first three years after a systemic banking crisis has no effect on the duration of the length of the stability period.

The duration of stability periods after a systemic crisis decreases with the level of the maximum of liquidity support in percentage of deposit that monetary authorities accorded to banks. It is however not influenced by the reduction of reserve requirements in the three years following a crisis.

Explained through information asymmetry and an increase in moral hazard, we concluded that only large-scale government interventions in banks, such as nationalizations, closures, mergers, sales, and re-capitalizations of large banks have a positive impact on the duration of stability periods, while recapitalization has a reducing effect on the length of stability periods after a systemic banking crisis.

Large-scale government interventions may help to restore the confidence in banks and to sustain accelerated recovery of the economy, while an adoption of IMF programs during and/or after a systemic banking crisis may be beneficial for a stabilization of the economy. 


\section{Appendix}

Figure 8: Representation of FMM parameters

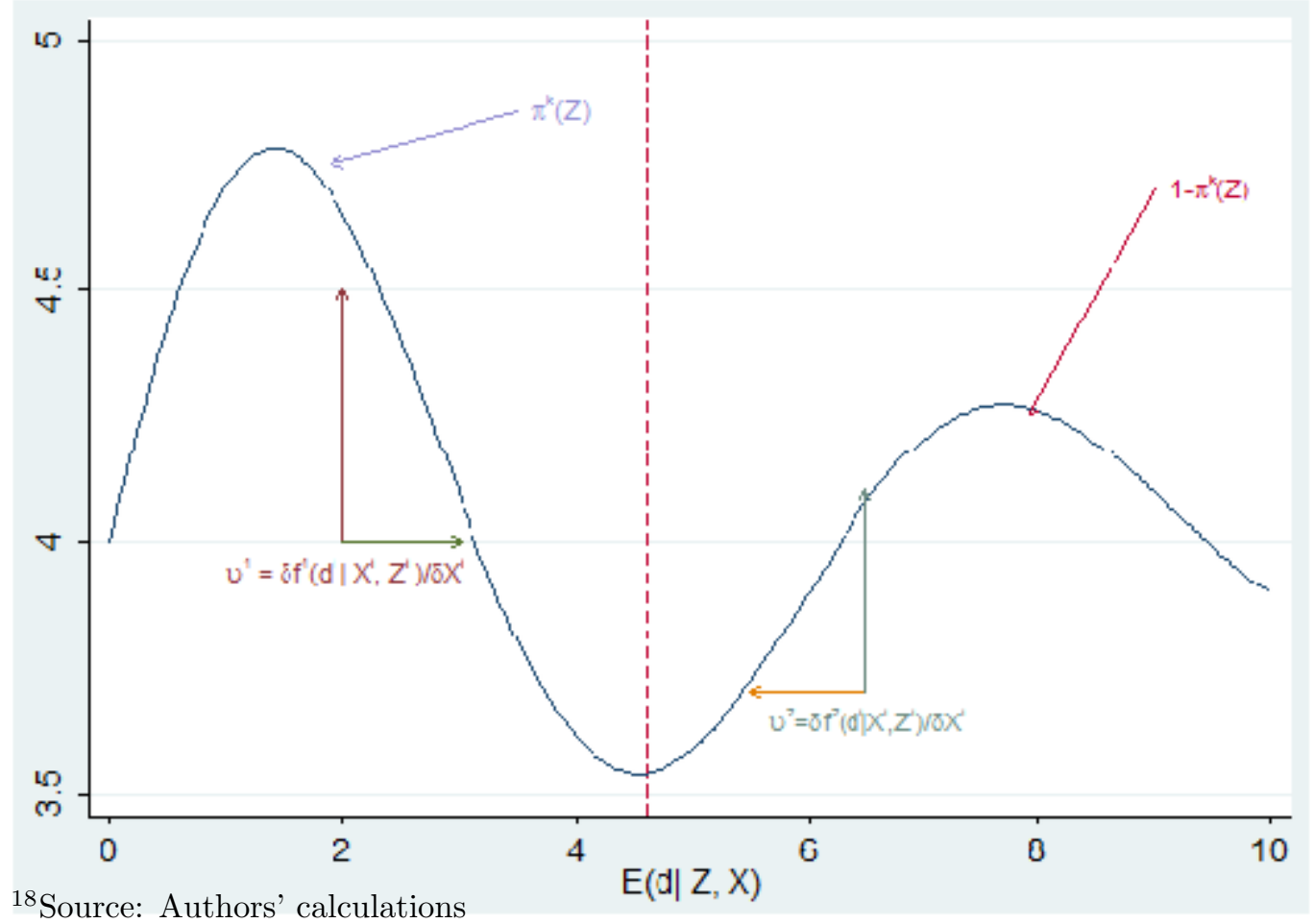

Table 10: Growth rate heterogenity according to duration subgroups

\begin{tabular}{cccc}
\hline GROUP & Real Variables & Financial and Monetary Variables & Equilibrium / External Variables \\
\hline Investment & M2/Reserves & Current Account / GDP \\
GDP per capita & Credit/GDP & Real Exchange Rate \\
Real interest rate & Net foreign assets / GDP & Terms of Trade \\
\hline
\end{tabular}


Table 11: Finite mixture model for Currency crises : Financial and Monetary variables

\begin{tabular}{|c|c|c|c|}
\hline $\begin{array}{l}\text { VARIABLES } \\
\text { m2reserve }_{G} \text { rowth3 }\end{array}$ & component1 & component2 & imlogitpi1 \\
\hline \multirow[t]{2}{*}{ m2reserve $_{G}$ rowth 3} & 0.101 & $-5.003^{* *}$ & 1.122 \\
\hline & $(0.552)$ & $(2.103)$ & $(1.014)$ \\
\hline $\mathrm{m}_{2}$ reserve $_{T R E N D d e v}$ & & $\begin{array}{l}-0.0008 \\
(0.0327)\end{array}$ & $\begin{array}{c}0.0119 \\
(0.0122)\end{array}$ \\
\hline creditgdp $_{G}$ rowth 3 & $\begin{array}{c}-0.729 \\
(1.902)\end{array}$ & $\begin{array}{l}-5.315 \\
(3.854)\end{array}$ & $\begin{array}{l}1.900 \\
(2.351)\end{array}$ \\
\hline creditgdp $_{T R E N D d e v}$ & & $\begin{array}{c}9.123^{* * *} \\
(2.961)\end{array}$ & $\begin{array}{l}-1.317 \\
(1.987)\end{array}$ \\
\hline nfaewngdp $_{G}$ rowth 3 & $\begin{array}{c}-0.885 \\
(1.071)\end{array}$ & $\begin{array}{c}14.46^{* * *} \\
(3.917)\end{array}$ & $\begin{array}{l}3.570^{*} \\
(2.080)\end{array}$ \\
\hline nfaewngdp $_{T R E N D d e v}$ & & $\begin{array}{c}0.435^{* * *} \\
(0.111)\end{array}$ & $\begin{array}{c}-0.0592 \\
(0.0457)\end{array}$ \\
\hline Constant & $\begin{array}{c}5.854^{* * *} \\
(0.304)\end{array}$ & $\begin{array}{c}8.726^{* * *} \\
(2.009)\end{array}$ & $\begin{array}{c}0.315 \\
(0.802)\end{array}$ \\
\hline lnsigma & $\begin{array}{l}-0.172 \\
(0.153)\end{array}$ & $\begin{array}{c}1.109^{* * *} \\
(0.114)\end{array}$ & \\
\hline Observations & 86 & 86 & 86 \\
\hline
\end{tabular}

Table 12: Finite mixture model for Currency crises : Equilibrium variables

\begin{tabular}{lccc}
\hline VARIABLES & component1 & component2 & imlogitpi1 \\
\hline cabgdp $_{G}$ rowth3 & -0.0726 & $-2.857^{*}$ & -0.0234 \\
& $(0.496)$ & $(1.503)$ & $(0.852)$ \\
cabgdp ${ }_{\text {T REN Ddev }}$ & & 5.138 & 1.969 \\
& & $(11.65)$ & $(4.659)$ \\
insreer $_{G}$ rowth3 & 0.192 & 6.434 & $8.431^{* *}$ \\
& $(1.743)$ & $(10.26)$ & $(4.221)$ \\
insreer $_{\text {T REN Ddev }}$ & & 0.00164 & -0.00114 \\
& & $(0.00839)$ & $(0.00554)$ \\
tt $_{G}$ rowth3 & $8.710^{* * *}$ & $32.29^{* *}$ & 5.613 \\
& $(3.301)$ & $(12.62)$ & $(5.972)$ \\
tt $_{\text {TRENDdev }}$ & & $0.0290^{* *}$ & $-0.0264^{* *}$ \\
& & $(0.0130)$ & $(0.0108)$ \\
Constant & $5.580^{* * *}$ & $15.24^{* * *}$ & $0.817^{* *}$ \\
& $(0.173)$ & $(0.973)$ & $(0.403)$ \\
\hline lnsigma & -0.0908 & $1.064^{* * *}$ & \\
& $(0.122)$ & $(0.137)$ & \\
Observations & 73 & 73 & 73 \\
\hline
\end{tabular}


Table 13: Simulation : Real Variables

\begin{tabular}{lccc}
\hline VARIABLES & & Coef. & p \\
\hline nir $_{G}$ rowth3 & comp 1 & 1.957 & 0.793 \\
gdppercap $_{G}$ rowth 3 & comp 1 & $5.889^{* *}$ & 0.82 \\
Realinterest $_{G}$ rowth 3 & prob & 2.472 & 0.85788382 \\
Realinterest $_{\text {TRENDdev }}$ & prob & -0.0744 & 0.83609959 \\
& & & \\
\hline
\end{tabular}

\begin{tabular}{lccc}
\multicolumn{3}{l}{ Table 14: Simulation :Equilibrium Variables } \\
\hline VARIABLES & & Coef. & $\mathrm{p}$ \\
\hline $\mathrm{tt}_{G}$ rowth3 & comp 1 & 8.710 & 0.863 \\
$\mathrm{tt}_{\text {G }}$ rowth3 & prob & 0.0290 & 0.916 \\
$\mathrm{tt}_{\text {TRENDdev }}$ & comp 2 & $32.29^{*}$ & 0.804 \\
cabgdp $_{G}$ rowth3 & comp 2 & -2.857 & 0.9 \\
insreer $_{G}$ rowth3 & prob & 8.431 & 0.86
\end{tabular}

Table 15: Simulation :Financial and Monetary Variables

\begin{tabular}{|c|c|c|c|}
\hline VARIABLES & & Coef. & $\mathrm{p}$ \\
\hline m2reserve $_{G}$ rowth3 & comp 1 & $-5.003^{*}$ & 0.82299084 \\
\hline $\operatorname{creditgdp}_{T R E N D d e v}$ & comp 2 & $9.123^{* *}$ & 0.82706002 \\
\hline nfaewngdp ${ }_{G}$ rowth 3 & comp 2 & $14.46^{* *}$ & 0.78738555 \\
\hline nfaewngdp $_{T R E N D d e v}$ & comp 2 & $0.435^{* * *}$ & 0.74465921 \\
\hline nfaewngdp $_{G}$ rowth 3 & prob & 3.570 & 0.87487284 \\
\hline
\end{tabular}


Table 16: Macroeconomic Indicators

\begin{tabular}{|c|c|c|}
\hline Variable Name & Description & Source \\
\hline gdpr & $\begin{array}{l}\text { GDP (constant LCU) from WDI extended using } \\
\text { WEO real GDP growth }\end{array}$ & $\begin{array}{l}\text { World Bank, World Development Indicators } \\
\text { (WDI), } 2009 \text { IMF, World Economic Outlook } \\
\text { Database (WEO), April } 2009\end{array}$ \\
\hline nir & Gross capital formation, constant prices & $\begin{array}{l}\text { IMF, World Economic Outlook Database (WEO), } \\
\text { April } 2009\end{array}$ \\
\hline gdppercap & $\begin{array}{l}\text { GDP (constant LCU) from WDI extended using } \\
\text { WEO real GDP growth divided by the population } \\
\text { as reported in the WDI, } 2009\end{array}$ & $\begin{array}{l}\text { World Bank, World Development Indicators } \\
\text { (WDI), } 2009 \text { IMF, World Economic Outlook } \\
\text { Database (WEO), April } 2009\end{array}$ \\
\hline Realinterest & Real Interest Rate (\%) & $\begin{array}{l}\text { World Bank, World Development } \\
\text { (WDI), } 2009\end{array}$ \\
\hline m2reserve & $\begin{array}{l}\text { Money and quasi money (M2) to total reserves } \\
\text { ratio }\end{array}$ & $\begin{array}{l}\text { IMF, World Economic Outlook Database (WEO), } \\
\text { April } 2009\end{array}$ \\
\hline creditgdp & Bank credit to private sector, in percent of GDP & $\begin{array}{l}\text { IMF, World Economic Outlook Database (WEO), } \\
\text { April } 2009\end{array}$ \\
\hline nfaewngdp & $\begin{array}{l}\text { Net Foreign Assets (NFA) divided by GDP (con- } \\
\text { stant LCU) from WDI extended using WEO real } \\
\text { GDP growth }\end{array}$ & $\begin{array}{l}\text { External Wealth of Nations, IMF, } 2007 \text { World } \\
\text { Bank, World Development Indicators (WDI), } \\
2009 \text { IMF, World Economic Outlook Database } \\
\text { (WEO), April } 2009\end{array}$ \\
\hline cabgdp & Current account balance to GDP, $(\%)$ & $\begin{array}{l}\text { IMF, World Economic Outlook Database (WEO), } \\
\text { April } 2009\end{array}$ \\
\hline reer & Real effective exchange rate index $(2000=100)$ & $\begin{array}{l}\text { IMF, World Economic Outlook Database (WEO), } \\
\text { April } 2009\end{array}$ \\
\hline tt & Terms of trade, goods and services & $\begin{array}{l}\text { IMF, World Economic Outlook Database (WEO), } \\
\text { April } 2009\end{array}$ \\
\hline
\end{tabular}




\section{References}

[1] Aitkin, M. (1997), "Contribution to the discussion of paper by S. Richardson and P.J. Green." Journal of the Royal Statistical Society B 59, 766.

[2] Adrian, T. and Shin, S. (2008), "Financial Intermediaries, Financial Stability and the Monetary Policy.", Federal Reserve Bank of Kansas City, 2008, Symposium.

[3] Bhatia, A. (2002), "Sovereign Credit Rating Methodology." IMF Working Paper n. 03/170.

[4] Bernanke B (2005), "The Global Savings Glut and the U.S. Current Account Deficit.", Remarks at the Virginia Association of Economists, Richmond, Virginia, March 2005.

[5] Borio, C. and Zhu, H. (2008), "Capital Regulation, risk taking and monetary policy: a missing link in the transmission mechanism?" BIS Working Paper, No 268.

[6] Caballero R., Farhi E. and Gourinchas P.O. (2008), "An Equilibrium Model of Global imbalances and Low Interest Rates." American Economic review, 98 (1), 358- 393.

[7] Canuto, O and Santos, P.F. (2004), "Dos. Risco- Soberano e Prèmios de Risco em Economias Emergentes." Temas de Economia International, Secretaria de Assuntos Internacionais, Brazilian Ministry of Finance, Brasilia, n.3, p.1- 43, Oct 2003.

[8] Cerra V. and Saxena S.C. (2008), "Growth Dynamics: The Myth of Economic Recovery." American Economic Review, 98:1, 439-457.

[9] Claessens S., Pazarbasioglu C., Laeven L., Dobler M., Valencia F., Nedelescu O., and Seal K. (2011), "Crisis Management and Resolution: Early Lessons from the Financial Crisis." IMF staff Discussion Note $\mathrm{SDN} / 11 / 05$.

[10] Chang, R. and Velasco, A. (1998), "Financial Crises in Emerging Markets." NBER Working Paper N. 6606, Issued in June 1998.

[11] Das, B. and Resnick, S, I.(2008), "QQ plots, random sets and data from a heavy tailed distribution." Stochastic Models.

[12] Day, N. (1969), "Estimating the Components of a Mixture of Normal Distributions." Biometrika Vol. 56, No. 3, Dec., 1969.

[13] Deb, P. (2008), "Finite Mixiture Model." Summer North American Stata User' Group Meeting 2008.

[14] Flood R.P. and Garber P.M. (1984), "Collapsing exchange-rate regimes: Some linear examples.", Journal of International Economics.

[15] Frankel, J.A. and Rose, A.K. (1996), "Currency Crashes in Emerging Markets: An Empirical Treatment." Journal of International Economics 41, 351- 366.

[16] FITCH RATINGS (1998), "Sovereign Rating Methodology." Nova York: Fitch Ratings ago.1998. 16p (Criteria Report). 
[17] Jordà, Ò., Schularick, M and Taylor, A M. (2010), "Financial Crises, Credit Booms, and External Imbalances: 140 Years of Lessons." International Monetary Fund Paper presented at the 11th Jacques Polak Annual Research Conference.

[18] Jordan, M. and Xu, L. (1995), "An Alternative Model for Mixtures of Experts." The MIT Press.

[19] Kaminsky G.L. and Reinhart C.M. (1999), "The Twin Crisis: The Causes of Banking and Balance-ofPayment Problems." American economic review, Vol.89, No.3, 473- 500.

[20] Krugman, P. (1979), "A model of Balance of Payment Crises." , Journal of Money, Credit and Banking.

[21] Krugman, P. (1999), "Balance sheets, the transfer problem, and financial crises." International Tax and Public Finance.

[22] Lane, P.R. and Milesi- Ferretti, G. M. (2007), "The external wealth of nations mark II: Revised and extended estimates of foreign assets and liabilities." 1970-2004, Journal of International Economics, Volume 73, Issue 2, Pages 223- 250 .

[23] Laeven, L. and Valencia, F.V. (2008), "Systemic Banking Crises: A New Database." IMF Working Paper No. $08 / 224$.

[24] Moody's Investors Service (2003), "Sovereign Bond Defaults, Rating Transitions, and Recoveries (19802002)." Nova York: Moody's Investors Services Fev.2003 a. 23p. (Moody's Special Comment).

[25] Melnykov, V. and Maitra, R.(2010), "Finite Mixture Models and Model-Based Clustering." Statistics Surveys.

[26] Merrouche, O. and Nier, E. (2010), "What Caused the Global Financial Crisis? Evidence on the drivers of financial Imbalances 1999- 2007." IMF Working Paper WP/10/268.

[27] McLachlan, G. and Peel, D.(2000), "Finite Mixture Models." Wiley Series in Probability and Statistics, Applied Probability and Statistics Section.

[28] Obstfeld, M. (1994), "The logic of currency crises.", Cahiers Economiques et Monetaires (Banque de France).

[29] Pearson, K. (1894), "Contributions to the theory of mathematical evolution." Philosophical Transactions of the Royal Society of London A 185, 71-110.

[30] Pearson, K. (1895), "Contributions to the theory of mathematical evolution, II: skew variation." Philosophical Transactions of the Royal Society of London A 186, 343-414.

[31] Reinhart, C. and Reinhart, V. (2008), "Capital Flow Bonanzas: An encompassing View of the Past and Present" NBER Working Paper 14321.

[32] Reinhart, C. and Rogoff, K. (2009), "This time is different: Eight centuries of financial folly" Princeton University Press; 1St Edition (September 11, 2009).

[33] Reinhart, C. and Rogoff, K. (2010a), "Growth in a time of debt" NBER Working Paper Series w15639, Jan.2010. 
[34] Reinhart, C. and Rogoff, K. (2010b), "From financial crash to debt crisis" NBER Working Paper Series w15795, March.2010.

[35] Sachs D.J., Tornell A. Velasco A., Calvo G.A. and Cooper R. N. (1996), "Financial Crises in Emerging Markets: the Lesson from 1995". Brooking Papers on Economic Activity, Vol.1996, No.1, 147- 215.

[36] Tudela, M. (2004), "Explaining currency crises: a duration model approach.". Journal of International Money and Finance, Elsevier, vol. 23(5), pages 799-816, September. 